\title{
Moving Up: Industrial Upgrading, Social Networks, and Buyer-Driven Commodity Chains in East Asian Chinese Business Firms'
}

\author{
RICHARI) P. APPELBALN

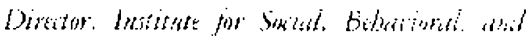

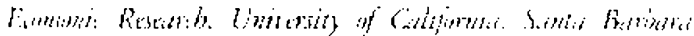

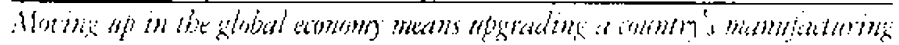

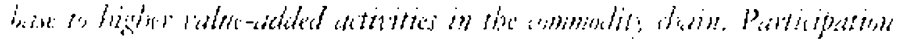

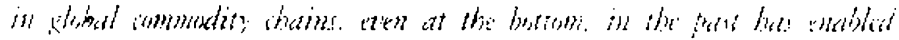

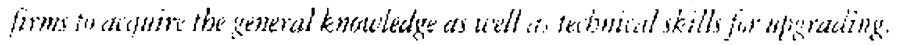

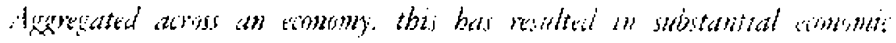

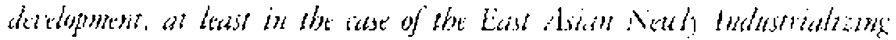

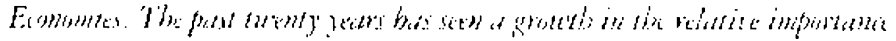

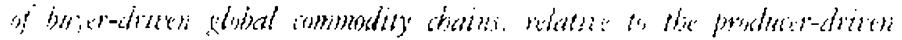

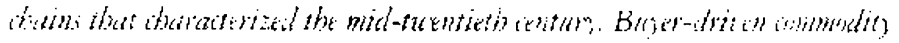

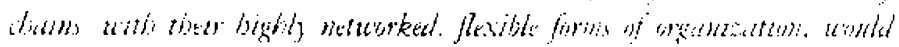

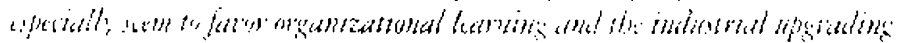

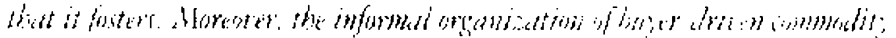

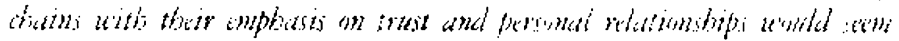

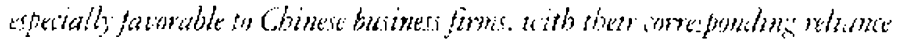

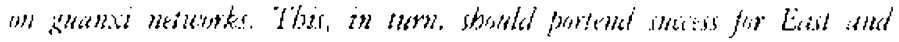

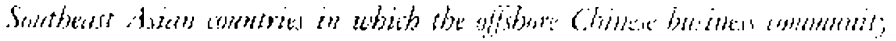

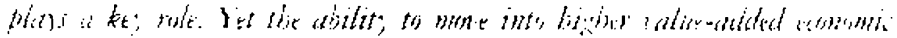

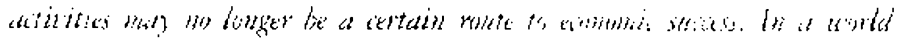

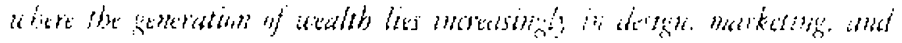

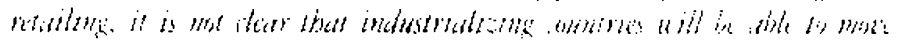

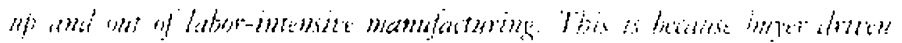

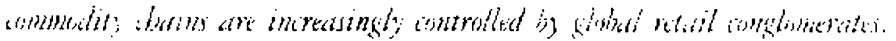

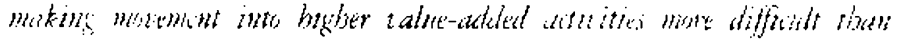
hitore.
\end{abstract}

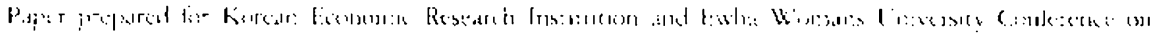

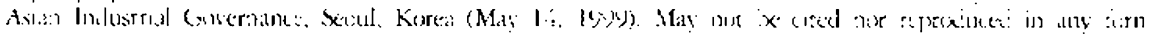

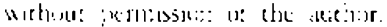

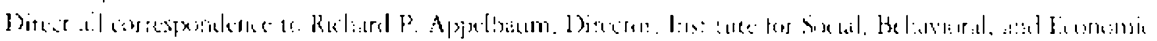

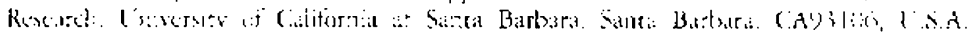




\section{IN'TRODUCIION AND OVERVIEW}

$\mathrm{F}$ or a country to move up in the global economy, it must upgrade its manufacturing base, rather than attempt to compete on the basis of low-cost labor. It is well understood thiat the developmental success of Iaiwan, South Korta, Hong Kong, and Singapore has been due at least in part to their firms' ability to upgrade into higher value-adcled economic activities. The Fast Asian Newly Industrializing Economies began as production platforms for core country firms, which enabled duem to cventually move into high-technology, high-value industrial production (Tawan, South Korea, Singapore) or high-end services (Hong Kong). Such upward movement has resulted from a combination of factors, including firm chatacteristics, the social orgatuzation of inclustries, and government policy. "Industrial upgrading" is assurned to be a kcy mxcharism of economic growth and an important strategy for national development.

The East Asian Newly Industrializing Economies have frequently becn hedd up as models for other less developed countries to emulate, with orher Southeast Asian nations such as Thailand, Malaysia, Viecnam, and Indonesia following in the footsteps of Hong Kong, Tawwan, South Korca, and Singapore (Kojima 1977; Yanazawa 1990; Inouc, Kohanja and Urata 1993). These most recent industrializers are all countrics in which Chineseentrepreneurs play key roles in their national businesscommunit ies. 'Their connections with Chinese businessmen throughout East and Southeast Asia give them a special edge in coordinating production among nerworks of small- and medium-sized enterprises. As 1 will argue in this paper, in the post-Fordist fexible production characteristic of much economic activity today, Chinese firms have a special advantage, one which wotd sect to offer the possibility of upgrading throughout much of this region, resulting in national economic development.

Yet the ability to move into higher value-added economic activities may no longer be a sure-fire route to exonomic success. In a world where the generation of wealth lies increasingly in design, marketing, and retailing, it is not cleas that industrializing countrics will be able to move up and out of labur-internsive manufacturing, following the lead of the late Fast Asian industrializers. The increasing importance of buyer-driven commodity chains, controlled by global retail conglomeraces, is making movement into higher value-added activities increasingly difficult.

\section{"MOVING-UP" INTO HIGHER VALUE-ADDED ACTIVITIES: THE EXAMPLE OF HONG KONG}

Capital in the world today is increasingly mobik, sceking out the best locations to maximize protits (Sassen 1988). Factories close in the older core regions of the world, only to open in the semi-periphery and periphery (Bluestone and Harrison 1)82; Caporaso 1981). Some theorists have suggested that this process of globalization has even undermined the viability of mass-production indust ries (Cerny 1995; Oman 14) 4 ; Doner and Herschberg 


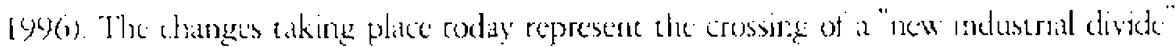

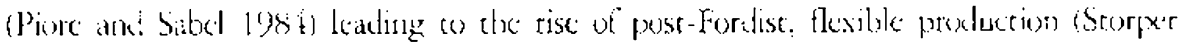
and Walker 1989); Sort 1988). Knowledge, rechoology, and analytic skills, aldong with che adrantages of flexibility, are key to success in textay's modern comperative indiustry. Malecti (1y9). 202) dains that increasingly, flexible, as upposed to rigid and stable, links alitow firms tis ik.just their acrivities to uncertainty ind co rapiclly shitiog conditions

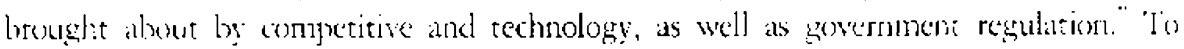

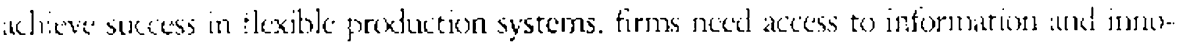

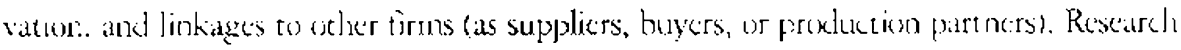

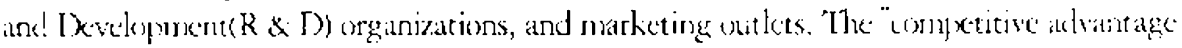
of nations" will le held by those who control key ted boologies and prextuction netwerks (Porter 12\%)

It is importint to reconmize that industrialization his different inpiats on economic development, depending on the specitic linkages that connect manufiacuringe enterporises

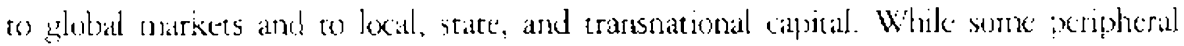

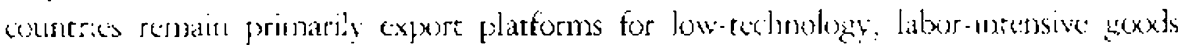

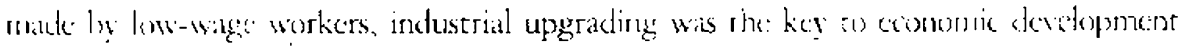
in mass: ot the Newly-Industrializing Exonomies of East Asia, ats they shiffed from manu-

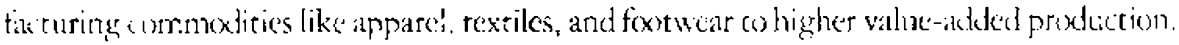
1)uring much of the past two decades, regional griowth rates averagcel alppruxinately $?$ percene a year - a rate which is extraordinary by workd stanclards (Numazaki les)8i. A combinition of state policies, private sector accivities, and ghobal economic corkliturs

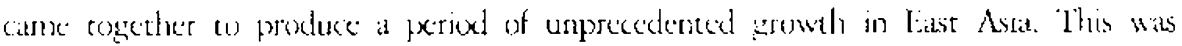

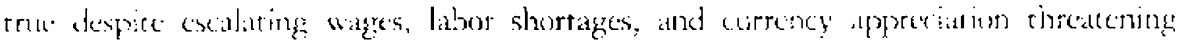

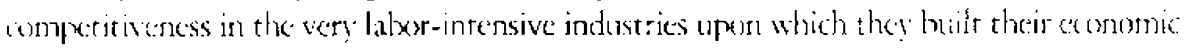

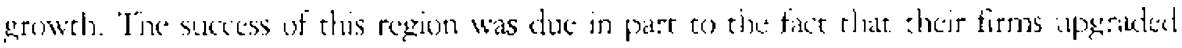
ines hegher value-adked activitits, shifting productos: to lower-wage areas.

Industrial wepgractinge can be defined as "the addetion of knowiledge with the potential of entancing the protit-generating capability of a tirm or an economy" (Ceretfi and lam

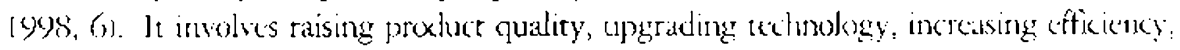

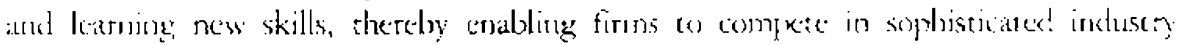

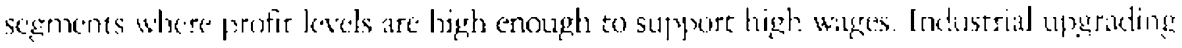

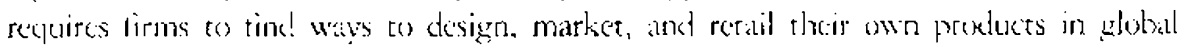
marke's, hecaking through che harriers to marke entry that are impxosed by companics

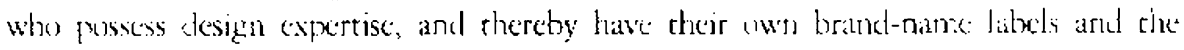
ablity to manpulate consumer tastes through alvertising ( Korecoicuic\% 19) i). In the

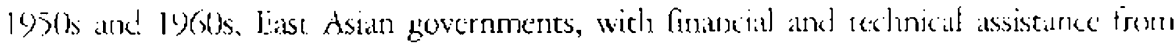

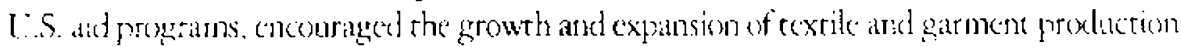

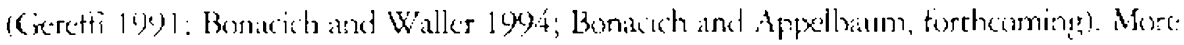

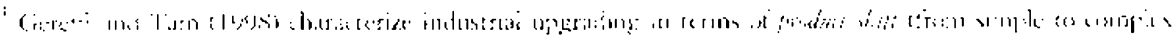

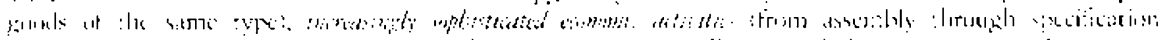

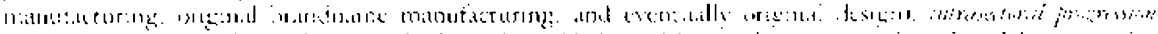

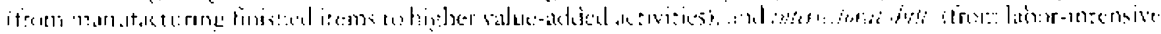

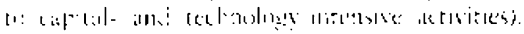


recendy, I long Kong, South Korea, and other more developed East Asian Newly Industrializing Econtumies have upgraded into the role of apparel sourcing and even design, while Clina and other low-wage countries have becone prine sources of apparel production.

Hong Kong's rise as an apparel manufacturing power is illustrative of the strengths - and pitfalls of "moving up" into higher value-added activities. Hong Kong's econonic: development hegan with Mao's victories in China in the inmediate post-war perisd. the tlight of industrialists from China brought capital, tectmology, and considerable know-low to Hong Kong. Slanghainese apparet manufacturers sparked cluc Hong Kong clorthing industry, opening the first coton sprinning mill in 1947. Apparel namufacturing peaked in the mid-1980, with more than 10,000 firms cmploying some $300,00(0)$ workers. By 1994, the number of workers $(137,000)$ was less than half the level of only a decade earlier (Hong Kong Industry Department 1991; Lall and Chan 1994; DeCoster 1996). Hong Kong's role in global apparel production has changed; it is now it command center for global garment sourcing, design, and retailing, with much of its proxluction (xcurring in China. Hong Kong brands sold diroughour the world include Giordano, with 500 recail outless in Asid, and Episcote, controlled by the Fang brochers, who began by making clothing for Liz Claiborne twenty yeats ago (Gereffi and Tam 1998).

Consider the example of one Chinese family conglomerate, the Wing-Tai family of publicly - and privately-held firms spanning East Asia. Wing-Tai was founded in 1955 by Cheng Yik Hung, who fled China and started the company in Hong Kong to make jeans for the British market (Kingman 1992). Wing-Tai opened a Singapxore oftice in 1962, when a quota was imposed on Hong Kong, and a Malaysia office in 1985. The ycars $1960 \mathrm{~s}-1970$ s witncssed an enomous growth in the demand for appared, exceeding Hong Kong's sapacity to produce. Wing-Tai saw its next $5(\mathrm{c})$ as getcing into wholesaling and distribution as well as manufacturing. By 1993 Wing-Tai had acquired controlling ownership of a number of apparel manufacturing companics, including Polly Peck in London, Haxter International in New York City, and Styl-land/PCH in Orange County, California. With its holdings encompassing apparel rnanufacturing, design, wholesaling, sourcing, and cven real estate development, Wing- $T$ ai (1991) aptly describud itself as "a diversified multi-national corporation with the confidence; ability, and determination to broaden the scope of its operations still further." One of Wing-Tai's holdings is the. Unimix Corporation, which was making cheap shirts for johbers on London's (onmmercial Street when Wing-Tai acquired it in 1987. By the mid-1990), Unimix liad become onc of Hong Kong's largest faccories under a single root, its 3,600 workers now making pricey shirts for a who's who of upscale European and North American labels (Tsang 1991; Tsang 1993). Yet even this upgrading strategy did not prove cost-cifictive. Hong

Hung Kong's chict manufdeturing induscries are rexcile, appard, clactronics, household elcstracil appliatices.

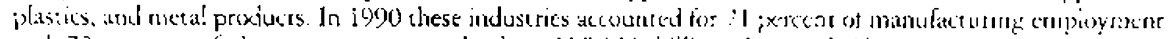

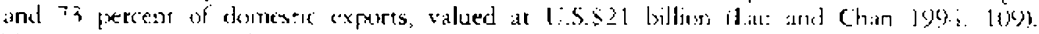

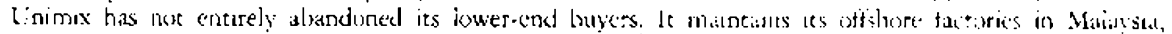

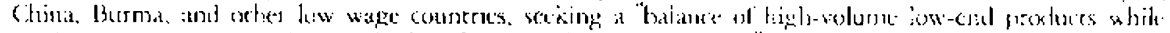

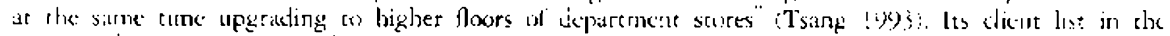

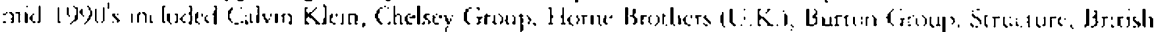

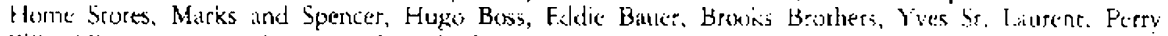

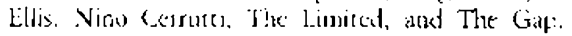




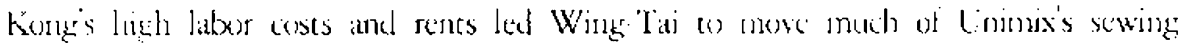

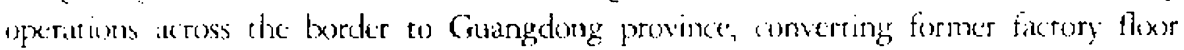
space into high-priced office rentals. Today, Unimix building renants inducte the heade puarters of it numlx.r of Wing-Tai's publicly-and privately-hold multinational businesses. Despite numeraus and conplex dealings with European, North American, and Japanese companies; Wing-'Fat remains very much a tamily business, with power residing in the three Li. educated soms of the toxinders.' Wing-Iai's global eperations are maintained through a cightly cexordinated metwork of fumilial and personal contacts.

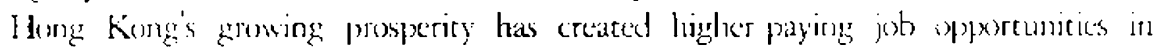
senice-oricuedel industries for the daughters of the women who once worked in its iow-stage garment faktories, who are toclay less willing ro work for apparel-industry wages (Tsang 1991; Lui 1991; Nig 1991; Ma 1991; Sung 1991; Lemg, 19916; Chengr 1991). Yet although Hong Kong has moved from manufacturing into scrices, this has no: meant cechnological upstaking on manuticturing. In fact, by the mid-1990 m, matudaturing contribured less than 10 percent to H long Kong's Cilsp, signaling the colongy's rapid transition to at

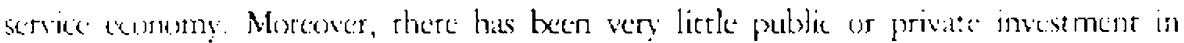

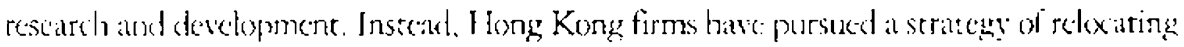
their factorices elscwhere in $A$ sia (and particularly in (hina), where: low wages compxinsire for a tailure to achieve productivity increase. Absent state incencives for und ustrial upgradings, or exen state-led ctforts to encourage technology transfer from transmational corjorations,

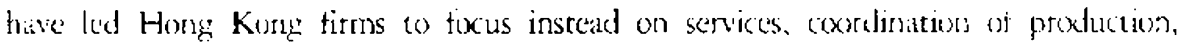
marketing: and prexluct development. It remains to be seen whether blong Kong can

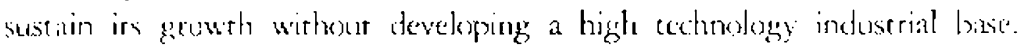

\section{FLEXIBLE PROILCTION: CHINESE BUSINESS CULTURE AND EAST ASIAN DEVELOPMEN'T}

Richard Whitley has argued that different cultures produce differeme cypes of business systems, "particular forms of economic organization that have become esrablished and reprodiced in cercain institutional contexts - loxal, regional, mational, or incernarional"

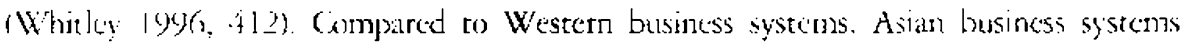

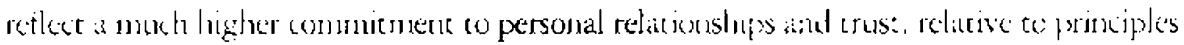

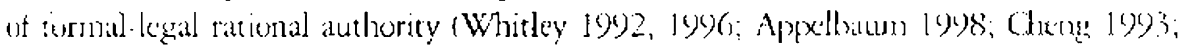

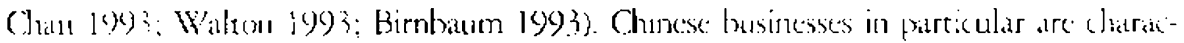
terized hy a heavy degree of reliance on intormal personal neeworks and connestions. Obligations with suppliers and other contractors rend w be short-term, unless they are related through ramily connections or comnunity ties. As a conseyuence risk is more likely ro $1 x$. transterred io subuontractors and partncts.

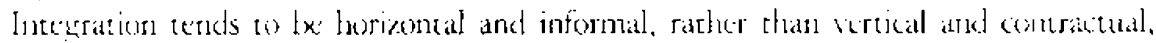

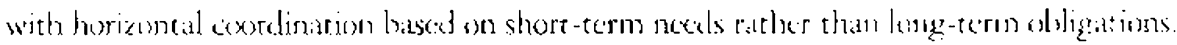

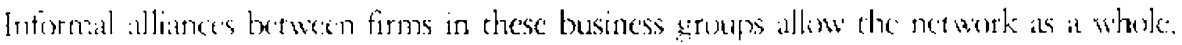

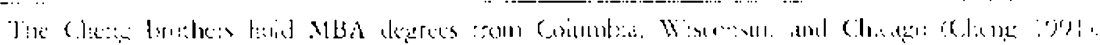


rather than individual firms, to organize and manage a large portion of the production and distribution proxess. Rather than using vertical inregration to solve problems of opportunism and information flow, these problems are managed through interfirm trust and conmunicarion. Firms can, therefore, remain small-and more responsive to quickly Changing market conditions, while at the same time gaining access to the large capital, resource, and information pools of the business group. There is evidence that smalland medium-sized enterprises nay be better able to respond flexibly to changing market conditions than large ones, particularly if they are informally networked into strong husiness groupings (Doner and Hershberg 1996). This is one of the most important organizational features of Chinese firms: they are organized informally through business groups, rather than through formalized relationships (Hamilton and Kav 1990; Snart and Smart 1991; Lui 1998; Whitley 1992, 1996). The organizational scyle of Chinese business firms bas an affinity with the increasingly common flexible torms of industrial orgarization, giving Chinesx businesses a unique advantage in the global economy tuday.

There is a large body of scholarship which argues that personal rclarionships, gutaxi. has long been a fundamental underpinning of Chinese business practices, which morcover helps to explain the success of Chinese merchants, traters, and businessmen throughour East and Southeast Asia (Bian 1994; Chan and Chiang 1994; DeGlispper 199); Hamilton and Feenstra 1997; Hamiloon and Kao 1990; Hamilton 1991, 1996, 1998; Mackic 1992; Orr, Biggare, and Hamilton 1991; Redding 1990; Tong and Yong 1998; Yan 1996; Yang 199). In particular, the institutionalized practice of grichaz the use of such relictionships to gain advantage undergirds much of the Chinese business culture. The "art of gremxi" involves "the exchange of gitts, tavors, and banquers; the cultivarion of personal relationships and networks of mutual dependence; and the manufacturing of obligation and indebtedness" (Yang 19494,6)."It thus carries the sense of social connections based on mutual interest and benefit: "Once gutunxi is established berween two people, cach can ask a favor of the other with the expectation that the debe incurred will bxrepand somenture in the future" (Yang 199/1, 1-2). "Indecel, it can be saisd that implicit in the very act of accepting [a gift, banyuct, or fasorj is an agreement in trust (o) repay in another form at a later date" (Yang 1994, 1/42).

Although some scholars have argued that the importance of zitanxi has diminished in the face of China's increasing incorporation in a global marketplace, it can be argued

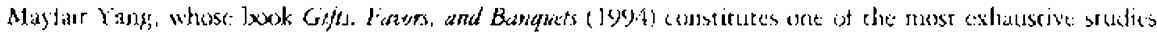

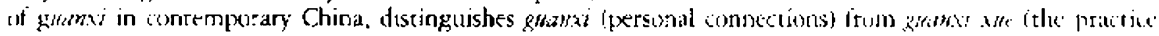

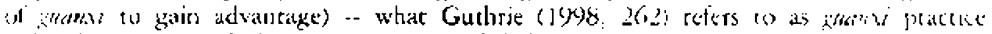

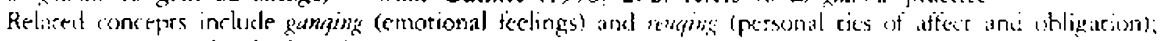
sec Vang (14)y to tor turther discussion.

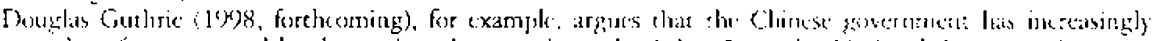
moved wo toser fanonal-legal practices. Latws such as the Labor Law. the National Compensation Liak.

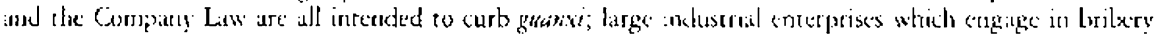

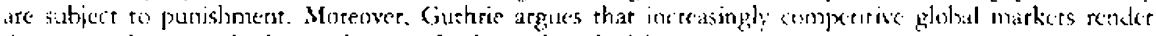

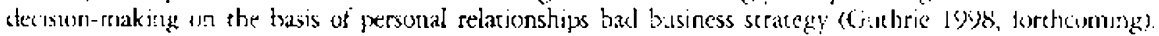

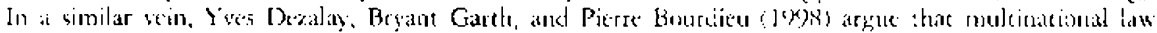

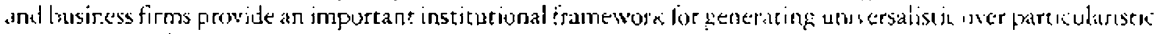

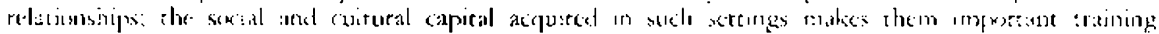

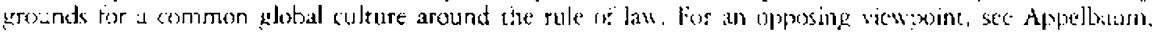
IM)
} 
that the upposite is trux. As Tai-lok Lui (1998. 337) notes,

What were once considered tradicional, particularistic, and inefficienc, such as small firms, craft proxtuction, and truse-based exchanges, are now cunceived as 'new' economic organizations and exchanges whoh can help encrepreneurs and etheir local and national economies to cope with a business environmetil (u) cunstant flux and uncertainty.

In the absence of vertically-integrated firms and a strong state role in enforcing inter-firm contracts, informal sucial networks provicle a principal means of reducing transacion costs (Landa 199. 4 , 1998). Stated sucincely, "trust makes metwork oryanizations viable" (1.ui 1998, 338).

This is not to argue that business relationships hased largely on trost are free from problcms: nepotism, favoritism, graft and corruprion are the aft cited downsides of doing business wherc "'tami is all-important. The Asian financial crisis of 1997-98 brought these problems to the fore, leading the very characteristies which had been lauded as key to the "East Asian miracle" to be denounced as calusing its downfall. As Hamilton (1999, 3) wryly observes. "The guanxi" relationships that comumentators had only a short cime carlice praised so highly were now vilified. Guand suddenly became cronyism, and the economics where these relationships occurred were now examples of "crony capitalism."

In fict, there is long-standing literature arguing that the Chinese firms and advanced (apitalism are antithetical \{Yoshihata 1988; Hwang 1981; Redding 1990; Fukuyana 1995), chanks to such osecnsive traits as "family ownership, patriarchal aurhority, problems with succession, lack of protessional management, weak employec loyalty, and relative lack of rescarch and development" (Hamilton 1999, 4). Yet in fact, the (hinese-based Last Asian exonomies weathered the "Asian flu" relatively well, and, as of this writing (fall 1.)\%), have recovered significantly. To holp safeguard against problems ot corruperion, Chinese businessmers are extremely cautious in establishing trust worthiness with the pople: they deal with (l.ui 1998, 3/4). Trustworthiness is established through prior performance, as well as restricting business relationships to one's own social circle - family and kinship group, people from une's ethoic or dialect group (i.e., place of origin), and close triends (Lui 1998, 346). Ever among those within what Lui( 1998,3 17) calls the "ghomxi boundary," trust cannot be caken for granted but must be continually demonstrated and earned. prowen ower a history of personaliced business transactions. Iruse is a form of social capital, certified by one's community: "The business transaction is no longer a private exelange carriced out in an anonymous marketplace, but ratler a soxial evert which is made visible and the participating agents are held responsible for the actuil handling: of the event in a proper way"(Lui 1998, 348).

Janct Tai Landa's 1981 , 199á, 1998) theory of ethoic trading networks argutes that

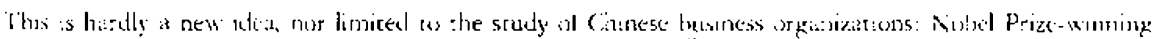

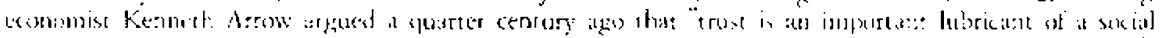

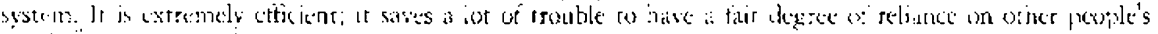

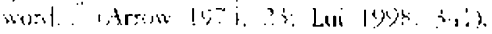


the existence of an ethnically homogeneous middleman group (E.HMG) is a principal means of introlucing certainty into economic transactions, as is evidenced by the operation of Chinese business groups:

The EHMG thus reveals itself to be a low-cost club-Jike institutional arrangement, serving as an alternative to contract law and the vertically incegrated lim, which smerged to economize on contract enforcenent and information cosis in an environment where the legal infrastructure was not well-developed (I anda 1981 ; reproduced in Landa 1994, 101-102!.

In her research on Hokkien-Chinese rubber traders in Singapore and W'est Malaysia, Landa found that although many factors were obviously important, trust fell off with social distance: it was generally highest for near kinsmen from one's imunediate family, diminishing as one moved out to distant kinsmen from one's extended family, clansmen, fellow villagers, fellow Hokkiens, non-Hokkien Chinese, and finaly non-Chinesc. She concludes that:

At the major exhnit: boundary, separating Chinese from non-Chinese, there is a sharp kink in transaction costs; this shapp kink in transaction coses is the major reason why (hinese middlemen belong to an ethnicality homogrenous group (Landa 1998, 10).

Chincse business groups arc comprised of firms formally iudependent of unc anuther but closely affiliated and ried by informal networks, epuity ties, and family relationships (Hamilton and Kao 1990; Orr, Biggart, and Hamilton 1992; Gerlach 1992; Granovettet 1993\%." Informal alliances berween firms in these large business groups allow the network as a whole, rather than individual firms, to organize and manage a large portion of the commodity chain. Rather than using vertical integration to solve problems of opportunism and information flow, these problems are managed through interfirm trust and cornmunication. Firms can, therefore, remain small and more responsive to quickly changing marker conditions, while at the same eime gaining access to the large capital, resource, and information pools of the business group.

The growing economic power of the overseas Chinese business community has grearly

\footnotetext{
"The imporrance of grama in linking an offshore Chinese business commu:uty long predares the moders]

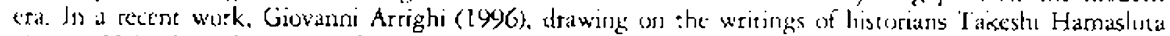

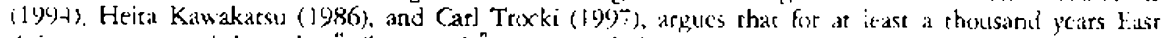
Asia wits untegrated through a "rribute-trade" system unified by an extensive Chini-cen:ereci trad:ng nerwork

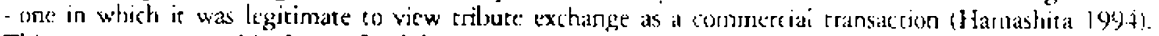
This system was notable for its llexibility, its loxseness, and its more or less segrmented structurc [which

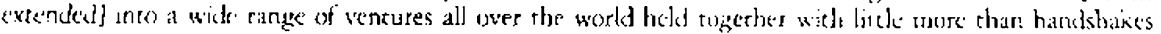

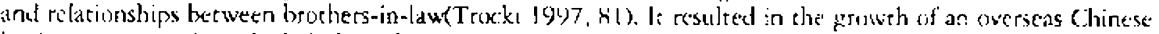

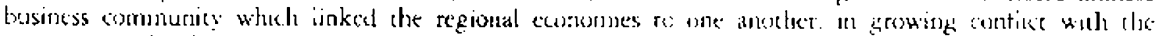

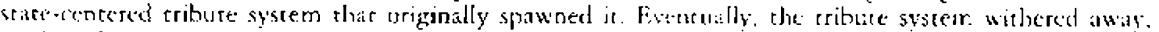

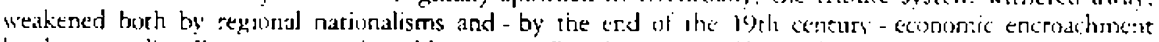

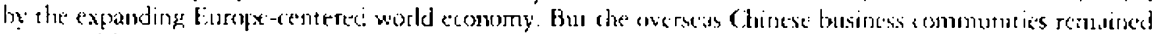

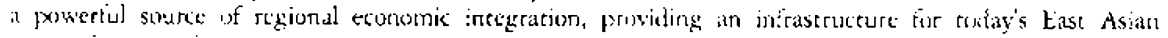

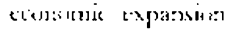


accelcrated with the incorporation of China into the world econony. Led by businessmen frum Hong Kong and China, uverseas Chinese entreprenceurs are the major investors in (hina, and are surpassed only by Japan in many Southease Asian countries (Naughton 1097: (hung 1497). As Hsing (1998, 152) points out:

A. estimated 51 million overseas Chinese in Asial creace L.S.\$450 billion gresss national product in 1990 (East Asia Analytical Enic 1995). Worldwadc, the userseas (hinese probably hold liquid asscts (not inciuding scrusities) worth \$3.5-2 trillion (the Fomomist 1992). The resources that the overscas Chinesc command, and the ransnational networks they create, potentially provike the techmologies. information, and finance tixols that China neteds.

Arrighi (199) 9, 9-10) conclucks that uversecus Chinese entrepeneurs are "emerging as a leading agency of processes of capital accumulation in East Asia." The it networks provide a significant advantage to the East Asian countries with significant Chnnese populations, as stated by Lee Kuan Yew, former President of Singapore, ar the 194) 3 World Chinese Ferteprencur's Convention in Hong Kong,

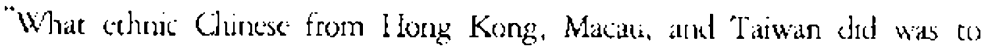
demonstrate to a skeprical world the ghemai comections chrough the same langunge and culture can make up for a lack in the sule of law and transparency in rules and regulations" (Ong 1997, 181).

Or: in the even more triumplatist language of the Singapore Chinese Chamber of Commerce and Industry (Nonini and Ong 1997, 4).

Today, there ars some twenty-five million ethnic Chinese outsike of (hina, the bulk of whom are concentrated around the fast-growing Pasific Rim. Individually and collectively, they are well-placed to play a key role in realizing the potential and promise of globalization, particularly in making the Pacific Century come tne.

In my uwn research on the global apparel industry, apparel executives in Hong kong and Los Angeles consistently assert that Chinese entreprencurs (whether in Los Angeles,

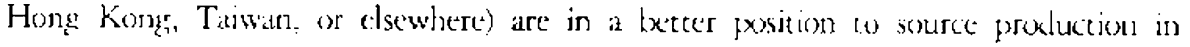
Asia than anyone else, largely because of their ability to clraw on wmand networks. The ability of Furopean and North American firms to opxrate sutcessfully in Fast Asia depend!s on their ability to work through such Chinese networks (Cheng 1943; (han 199); Walton 19937. In one survey of Los Angeles' 184 largest apparel manufacturers, for example, it was found that three-quarters of Chinese-owned apparel manufacturing firms produced in Asia-compared wich only a guarter of all tirms owned by Koreans, and almost no firms owned by Lacinos, who tended to contrace for sciwing in Los Angeles (Borlaticl and Appellyaurn, forthoming).

I have found numerous cxamples of the central role: of personal connections, in ans

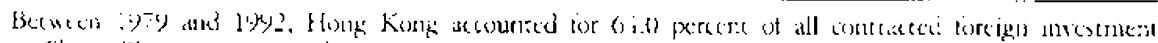

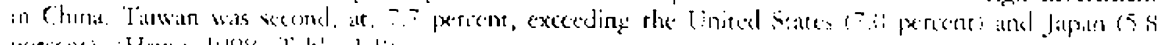

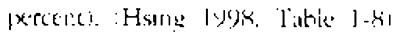


industry where orders take place on a handshake. As Jirn Cunninghan, 'Ihe Giap is Vice President for Offshore Sourcing explaincd, with the exception of Korea and Japan, "Every country's apparel industry is dominated by ethnic Chinese, the merchants of past centuries, who live in Chinatowns the world over branches of families from the same province. In this business, things take place on trust" (Cunningham 1991). Even the largest Europcan or N)rth American retailers and manufacturers cannot ordinarily access Chinese factorics directly: typically, they must work through Hong Kong or Tawanese intermediaries (Waton 1993).

In sum, in a world in which tlexible production frequently relies on informal relationships and personal contaces, the overseas Chinese business community is well-situated to play a pivotal roke. To heter anderstand how this works as well as some of the constraints on upgrading that firms are likely to face - it is useful to cxamine the changing natuse of global commodity chains, the principal networks that link firms together in the global economy.

\section{GLOBAI. COMMODITY CHAINS AND INDISSTRIAY. UPGRADING}

The notion of an increasingly integrated global economy - where countries come to occupy distinct export niches and where industrial upgrading is a key strategy - can be fruitfully understood through the notion of global commodity chains, "nerworkis of lator and production processes whose end result is a finished conmodity" (I Lopkins and Wallerstein 1986, 159). Global commodity chains consist of a number of opetations that comprise pivotal points in the producrion precess: raw materials supply, production, export, and markecing, taking us "across the entire spectrum of activities in the worldeconomy" (Gereffi 1992, 94). They have four main dimensions: an imput-suttit struture comprised of a set of products and services linked together in a secjuence of value-adding economic activities; at itmionality that identifies the geographical dispersion or concerttration of raw material, production, export, and marketing networks; a sontmome srmitur of power and authority relationships that detcrmines how financial, naterial, and human resources, as well ats economic surplus, are allexated and flow within a chain; and an institutimad settims - the local, national, and international conditions that shape its activities (Gereffi and Tam 1998).

Global inequality, development, and underdevelopment of cotincries as a whole are defined by the differing positions countries occupy in these multiple net works of workdwide economic proxluction and exchange. Differential profit and surplus are gencrated at various nodes along commodity chains. These patterus are nor entircly uniform, and the highest profits and lasgest surplus extraction are not always located at the leginning, middle or end of the commodity chain, but vary according to particular circumstances and specific commodities. Commodity chains are especially important because they determinc the relationship between particular firms and global production proxesses.

A firm's role in a global commodity chain pernits it to learn new activities, thereby providing opportunitices for upgrading. To the extent to which tirms that specialize in 
asscmbly arc embedded in global networks that encompass design, marketing and sales as well as production, they are more likely to acquire the organizational and technological know-how that is necessiry in order to move from asscmbly into highter valuc-aided activities. Drawing on the organizational literature, Grereff and Tam $(1998,11)$ distinguish between three kinds of economic relationships: market (arms-length, governed by supply and demand), hierariby ("vertical," governed by authoritarian relationships), and neturyk (loose but stable relationships, governed by trust, rcciproxity, and openness). They argue that networked relationships are more conducive to organizational Jearcung than market or hierarchical ones, because they are more likely to lead to open slaring of organizational praciecs, technological understanding, and other forms of knowledge that could enable. a firm to upgrade.

In terms of the present discussion, networked ccononic relationships are typical of Chinese business firms, which might, therefore, he expected to have an advantage when it comes to organizational learning and consequcntly industrial upyrading. For example, as mentioned earlicr, in the 1970s Hong Kong's Fang brochers began as makers of apparel for Lic Claiborne. Through their manufacturing activities they learned how to organiac production, manage quotas, and eventually provide full-package production by sourcing suppliers throughour Asia. Eventually, they also acquired the krow how to engage in design and retailing as well, and currently market cheis own brand of worneris clothing, Episode, through stares in 26 countries throghout the workd (Cereffi and Tam 1998). The ability to provide full-package production has teen key to the success of Hong Kong, Tawanese, and South Korean apparel firms in penetrating North Anxerican, European, and Japanese apparel markets. Apparel suppliers in these countries had to acquire the know-how to do everything, since the core country retailers and manutacturers who used their scrvices did not know how to make garmenes in low-wage countrics. During the course of providing such full-package services, the suppliers also learncel bow to design and market their own lines of apparel. China, Mexico, and Tutkcy are now acquiring full-package capabilities, and may be expeced to move up the commodity chain into bigher value-added activities as well (Gereffi and Tam 1998). In fact, as post-NAFlA Mexico replaces Hong Kong, Taiwan, and China as the principal exporter of textile and apparel to the United States,'- 'Iaiwanese atd mainland Chinese rextile

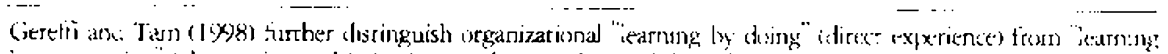

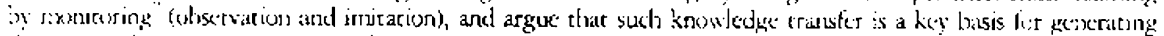

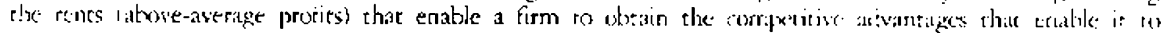

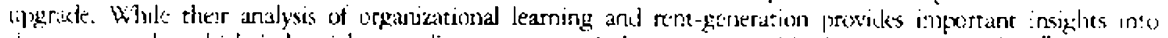

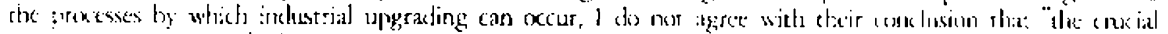

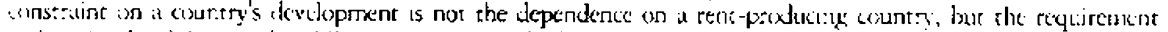

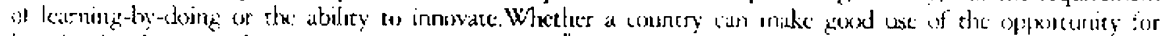

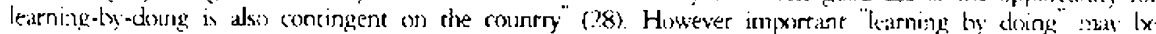

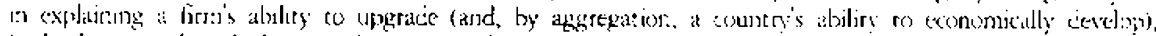

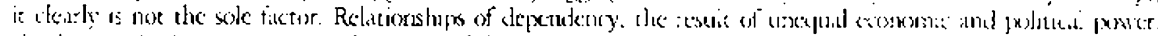
clearly rem:ain important in explaining mubility within the werld-swstem.

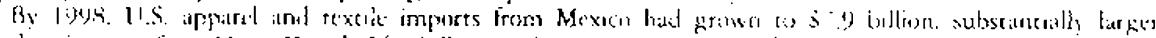

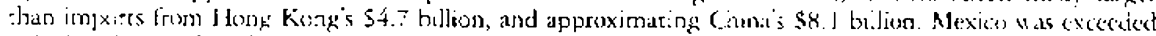

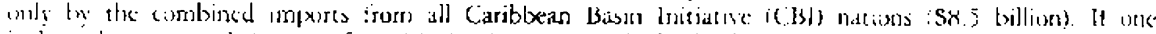

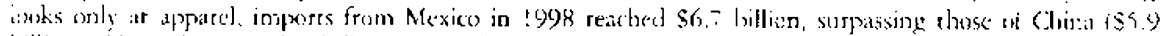

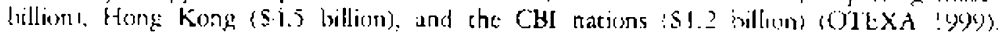


and apparel firms are likely to become increasingly involved in joint ventures with Mexican firms, enabling the Asian firms to enter the United States through NAFTA's back dour. Ihe Asian companics provide the know-how for engaging in full-package prorluction; the Mexicat firms, for the moment, specialize in assembly work.

To better understand the prospects for industrial ungerading as a means of mobilicy in the workd economy today, it is useful to distinguish between two different typx:s of global commodity chains - those that are producer-driven, and those that arc buyer-driven (Gereffi 199.1).

\section{PRODUCER-DRIVEN COMMODITY CHAINS: A DIFTICULT ROUTE TO UPGRADING}

Producer-driven commodity chaius are found in those industries "in which large integrated industrial enterprises play the central role in controlling the prexduction system (including its forward and backward linkages)" such as automobiles, computers, aircraft, and electrical machinery (Appelbaum and Gereffi 1994, 44). The structure is most characteristic of capital-and cechnology- intensive industries dominated by transnational corporations, where "large integrated industrial enterprises play the central role in controlling the production system" (Appelbaum and Gereffi 1994, 4/4) and profits derive primarily from "scale, volume, and technokgrical advances" (Gereff 1994, 99). The principal protits in producetdriven conmodity chains are typically associated with the corc manufacturing stages, and are derived from economies of scale and scope, production volume, and advanced rechnology. They include such activities as research and development, product conception, and product design, all activitics associaced wirh production rather than consumption.

The barriers to entry in profuces-driven commodity chains are likely to be high, making this a difficult path for a country unless it has achieved a fairly high level of economic development. Barriers include costly raw materials, rechnologies, skilled labor, and capital equipmenc, not to mention the internalization of risks in a production process where much of the commodity chain is located within a single firm. As a result, a handful of proxlucers dominate their retajlers, and often control them outright, as in the saltes of automobile through eightly-controlled frandised dealerships. In South Koreas Singrapore; and Taiwan, industrial upgrading has historically moant moving into producer-driven chains only when a certain level of development is achieved-and then usually with considerable governmental support (Henderson and Appelbaum 1992).

\section{BUYER-DRIVEN COMMODI'IY CHAINS: A PATH TO UPGRADING AND DEVELOPMENT?}

Buper-driven commodity chairs are found in those industries where "large retailcrs, 
brand-named marketers, and trading companies play the pivotal role in setting up decentralized production networks in a wide range of [low-wage] exporting councrics" (Appelbaum and Gereffi 1994, 44). Historically, buyer-driven commodity chains have predominared in labor-intensive, consumer goods industries such as garments, footweat; toys, and consumer electronics. Beginning in the $1970 \mathrm{~s}$, buyer driven commodity chains have become increasingly important in global production; teday they predominate in the "Alcxible" forms of post-Fordist proxluction that play a majur role in the workl conomy.

Since lal orr interisive buyer-driven commodity chatins hatwe relatively low start-up cosss, barriers to entry are few. This results in a large number of producess in comperition with one another, who are dominated by much more wealthy and powerful retailers. The principal profits are not generated at the production end of buyer-driven commodity: chains, but rarher at the retail end. Profits derive from "unique combinarions of high value research, design, sales, after-sales services, marketing, and financjal services that allow the buycrs and branded merchandisers to act as strategic brokitrs in linking iverscas factories and traders with evolving producr niches in their main consumer narkets" (Gereffi 1994, 99). In other words, the highest value-added activities are of ten more closely associated with consumption than with production. Bccause constant design changes for customized markets are the primary source of competitive advantage, prodarts must become increasingly aestheticized. Emphasizing elements of style, fard, and mystique underscores the contribution of design to the value of the product. Design-intensive activitics thus increase their proportion of value compared to manufacturc and assenbly activities (Harvey 1989; Sout 1988; Lash and Urry 1994).

While some peripheral councries are primarily export plat forms for simple, low-rechnology. lalkr-intensive goods made by low-wage unskilled workers, orhers have engaged in industrial upgrading, shifting from commodities like textiles, apparcl and foorwear to higher valuc-added, technologically sophisticated production reguring a strong and well-integrated industrial base (Gereff 1992). This pattern may involve the continuous technological improvement of production processes, but it may also invalve the creation of new products, and new services, in general engaging in higher value-added economic acrivities. High-quality production, honed by discersing local markers and fueled by the selling of design and style, can assure global competitiveness even in an era of strong wage competirion. Competitiveness in quality and imagre rather than in labor costs, is clearly the key to longer-term global success. Since the protits in buyer-drivern global conmodicy chains lie in the design, marketing, and retailing phases of the comnodiry chain rather than in production itself (Appelbaum and Gereffi 199\%), it would seem especially important for exporting councries to emphasize these high end activities over cost-comperitive manufacturing. Firms that initially specialize in specification contracing may cventually move to their own designing and retailing through the "urganizational learning" resulting from participation in the commodity chan (Gereffi and Tam 1908 . 


\section{THE RETAII, RFVOLUTION AND INDUSTRIAI, UPGRADING;}

Buyer-driven commodity chains are typically associaced with the flexible production characteristic of Chinese business systems. 'This might lead one to conclude that in an exonomic world where informal networks teplace formal bureaucratic structures, the Chinese business culture will thrive, cnabling the industrializing cconomics of Fast and Sonthe ast Asia ro experience a degree of developmental success. Gary Hamilon (1998, 2), in an unpublished paper, goes so far as to argue that the $1998-99$ "Asian tlu" was party the result of a global shift in production from vertically-integraced mass production to horizontally-integrated "demand-responsive reflexive manufacturing systems" - a shift which in the long run scrongly favors Chinese (as opposed to Korean and Japancse) manufacturing methods. In other words, the global shift from protucer-to buyer-driven commodity chains favors Chincse businesses, and by implication those cconomics in which such business systems doninate.

Yot if the good news is that the movement towards buyct-driven commoxtity chains favors the flexible forms of production that characterize Chinese business networks, there is some bad news to go along with it: the retail consolidation of the past decade has made it increasingly difficult to move up the commodity chain inco higher value-added activities such as design and marketing. Even manufacturers are being squeczed out of the buyer-driven cormonodiry chain. Retailing is no longer controlled by manufacturers; it is now clearly driven by large retail buyers (Jones 1993)." By the next millemium, according to industry analysts Kurt Salmon Associaces (KSA 1940), retailers who are not solidly enrenched in one of three niches - high service level, low price values, or unique merchandise - arc not likely to survive. In a world of buyer-driven commodity chains dominated by a handful of global retail corporations, it becomes harder to move up the commodity chain to where the principal profits lie.

In the U.S. apparel industry, for example, private label production now accounts for as much as a third of all recailing. with many manufacturers reduced to suurcing production for gian retailers. Between 1970 and 1950 , the number of shopping centers in the Uniced States grew from 10,000 wo 37,000 , as mass merchandisurs and deparnume store chains, mec the major powers in the industry, found themselves increasingly squeceed by discounters offering lower prices for quality goods, and specialty stores offering a more clearly defined range of products coupled with a high level of service (Stejnherg 1996. 3). As a consequence of such intense competition and excess capacity, a large number of uell-publicized mergers and leveraged buyouts occurred in the late 1980s, as retailing consolidated into a shrinking number of giants. During the early 1990), many of these newly-consolidated retail conglomerates filed for bankruptcy prorection, sepueend between the debt they had acquited to finance their metgers, and the retail recession. This resulted in still further consolidation, as a tandful of grants many of them discounters - came to dominate the L.S. retail landscape. Wal-Mart. for example,

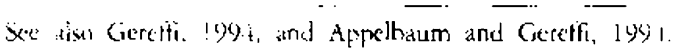


is the world's largest retailer, with operations in Canada, Latin America, Asia, and Eurupe as well as the Liniced States. With 1999 sales of $\$ 138$ billion 117 percent highthet than 1948) and a workforce of 825 , (4)(0), Wal-Mart overwhelns the retail landscape, accounting for more rctail sales than its three nearese rivals combined (Hoovers 19y9). In fact, the four largest U.S. retailers accounted for more than $\$$ ? 1 t billion in sales, approximately two-thirds the I:S. toral.

In sum, the shiff from producer-driven to buycr-driven global commodity chains has been accompanied by an enormous concentration of power at the top of the chain. Large retialers are able to garner an increasing share of the surplus at each level below therr, while impeding progressive movement into higher value-added activitics. What was once a possible avertuc for upward mobility through industrial upgrading now appears (o) be a major bottleneck. It may still be relatively casy for firms with little capital but cheaper lator to enter the commodity chain at the botom, but their chances of moving up are increasingly circumscrited.

\section{CONCLUSION: WILL RETAIL CONSOLIDA'TION IMPEDE INDUS- TRIAL UPGRADING?}

I low likely is it that the experience of the "four tigers" will bxe replicated throughout Asia? Their path to development began on the bottom rungs of huyer-driven commodity chains in apparel, electronic assembly, and other low-wase production activities. Industrial upgrading into higher value-added accivities, along with the cultural and social capiral that was acquired along the way, helped to foster thcir economic devclopment. Eventually, aided by government programs and economic assistance from the United States, firms in these cronomies - with the exception of Hong Kong - evern developed their own proxucerdriven commoxlity chains in automobile manufacturing and other industries.

Today the remere upward has changed. On the one hand, the growing imprortance of buyer-driven commodity chains - with their flexible structure. extcnsive contratring systems, and informal networks of relationships woukd secm to strongly favor Chincse business firms, which have long operated along similar lines. The appearance of this organizational form in industries such as automobile manutacturing, once the exclusive province of producer-driven chains, offers the possibility that conteactors in capital-ineconsive industries might eventually nove up into higher valuc-akded activities.

On the other hand, the enormous power accumulated by retail conglonerates to control the cumonofity chains makes it more and more clificult for firms that enter at the botrom to move up." The profits - and power - lie with the retailess and manufacturer/

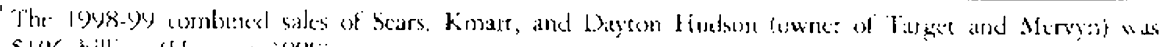

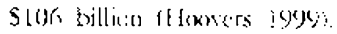

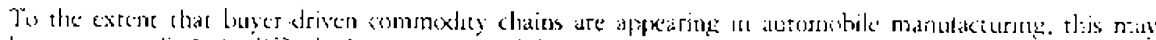

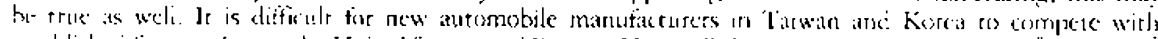

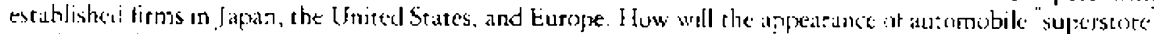

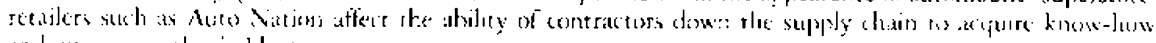
asted mow up she ialdider?
} 
designers, and even the latter are being squeczed out. The historically proven upward path - from simple assembly, to specification contracring. to designing and markcting one's own brands - may be a much more difficult onc to pursuc texday. Feven firms that gain the necessary know-how by beginning at the botrom may find that the route upward is closed off.

Nor is it clear that conditions still exist for the state to foster movement into more capital-intensive producer-driven commodity chains (Henderson and Appelbaum 1992). These conditions once included the Cold War. which funneled vast amounts of foreign ad into the region; 16 world trade expansion, sustaned by the long boxm in the core economies during the 1950s and 1960s; and the crucial role of the developmental stare; which frequently kept wages low through labor repression and subsidies in elc form of cheap public bousitug, provided heavy investments in education and training, and pursued various torms of industrial policy buring the latter phases of export-led growrh and secondary import substitution as in South Korca, Taiwan, and Singapore.

It seems unlikely that such policies and conditions will be replicared elscwhere in the world in the near future. The Cold War has ended, and with it the imperus for the Lnited States and other nations to support economic development chrough foreign and mulitary aid. Global conomic slowdown has dampenct the markets for proxlucts from the late industrializers, raising serious questions alomt the efficacy of export-oriented industrialization. A central role for the developmental state, once aggressively pursued throughour East Asia, is today challenged hroughour the workl. The collapse of state socialism has contributed to the hegemony of a powerful neoliberal ideology that celebrates market reform as the exclusive panacca for economic success. We have seen the results of this approach throughout the world, from Russia to bast and Soucheast Asta to Latin America, and they do not portend well for global economic growth.

At the noment, the possibilities for industrial upgrading remain unclear. Although informal, more flexible forms of production invite the parcicipation of firms throughout the world, and would particularly seem to favor Chinese forms of entrepreneurship, the ascendant forms of production are accompanied by a retail restructuring that may create the upposite effect. It remains to be seen how these forces play ilemselves out in the near future, or whether something entirely new wibl alter the nature of global commodity chains in unforeseen ways - for example, the explosive growth of web-lyased retailing,"

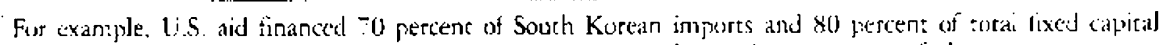

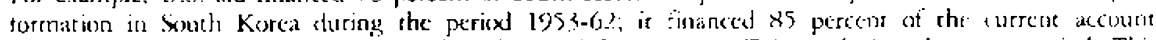

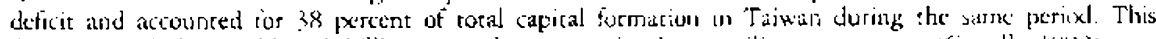

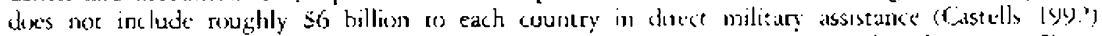

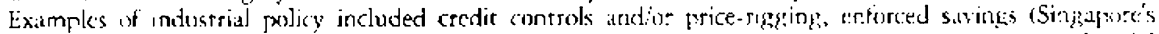

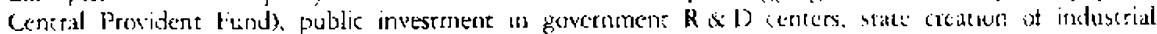

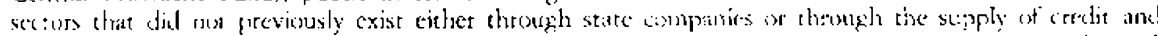

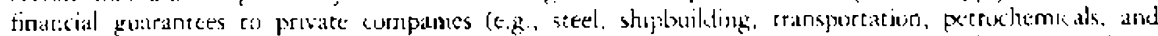

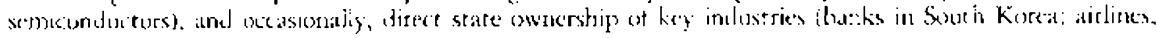
armaments, and ship-reparting in singapore:

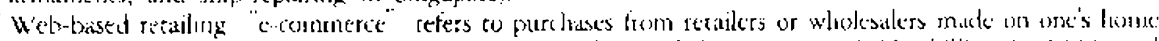

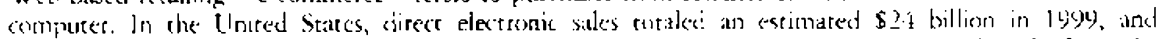

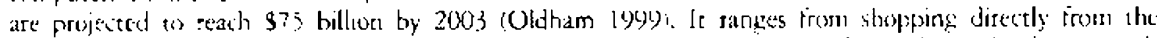

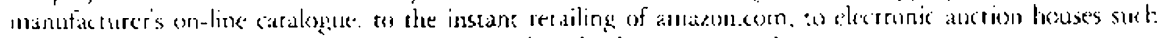

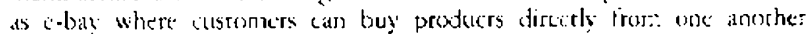


which will enable consumers to bypass conventional retailers altogether.

\section{REFERENCES}

Appeibaun, Richarci P. 1998. "The Future of Law in a Global Country." Srcial or lezal Strides 7 (2) (June): $171-92$.

Appelbaum, Richard P. and Gary Gereffi. 199.1. Powes and Profits in the Apparel Cummodity

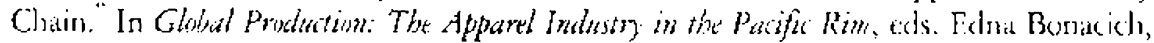
Lucie Cheng. Norma Chinchilla, Norma Hamiton, and Paul Ong. Philadelphia, Pa.: Temple Universicy Press.

Arrighi, Giovanni. 1994. The Long Twenteh Century. London: Verso. 1996. "The Rise of East Asia and the Withering Away of the Interstate Syscem." Journal of World-Systems Researth 2:15.

Arrow, Kenneth, 197. T. The Limits of Organizatisn. New York: Nortun and Company. Bian. Ianite. 1994. "Gisomi and the Allocation of Cirban Jubs in China." The Cbima On:merly 1 (10) (December): 9/1-90).

Birnbaum, David G. 1993. President, Third Horizon I.cd., Homg Kung (Brad Christerson interview, July $1 \%$.

Bluestone, Barry and Bennet Harrison. 1982. The Demdustrialiation of Amertai. New York: Basic Books.

Bonacich, Edra and David Waller. 1994. "Mapping a Global Industry: Apparel Production in the Parific Rim Triangle." In Glatal Prodution: The. Apport Industo in the Patific Rim, eds. Edna Bonacich, Lucie Cheng, Norma Chirnchilla, Norna Hamilton, and Paul Ong. Philadelphia, $\mathrm{Pa}$ : Temple Liniversity.

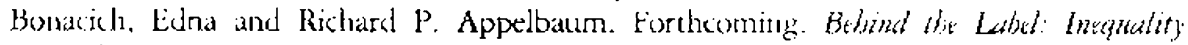
in the Jar Alegeter Garment Indestry. Berkeley, Calif: Iniversity of California Press.

Capurasu, Janes. 1981. "Industrialization in the Periphiry: The Evolving Global Division of Lator." Intrmational Simles Quarterly' 25 (3): 34:-84.

Castells, Manucl. 19)2. "Four Asian Tigers Wit h a Dragon Heaci: A Comparative Analysis of the Statc, Ecomomy, and Suciety in the Asian Pacific Rim." In States and Demthoment in the Fast Asion Parfic Rim, eds. Richard P. Appellsaum and Jeffrey Henderson. Newbury Park: Sage.

Cerry. Phillip G. 1995. "Globalization and the Changing Logic of Collective Action." Intrmationd Organisation 49) (4): 595-62.5.

Chan. Joseph. 1993. General Manager, Innova Led. Hong Kong (Appetbaum intervicw, April 22 and May 2).

Chan. Kwok Bun and Claire Chang. 1994. Stepping Out: The Wlakng of Chineje Entreprenenrs. linglkword Ciffs, N.J.: Prencice-Hall.

Chengr, Francis Man-Piu. 1991. Assistane Managing Director, Wing-Tai Exporecrs, I.td., Hong Kong (Richard Appelbaum interview, November 25).

1943. Assistant Managing Director, Wing-'Tai Exporters, J.td., llong Kong (Chrisierson incervicw, July 19$)$.

Chung. Chin 1997. "Division of I.abor across the Tarwan Strati: Macro Overview and

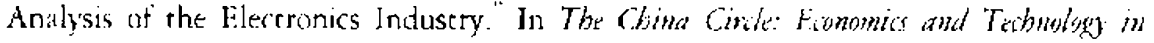
the PRC. Tainans, and Iong Kong, edited by Barry Naughton. Washingtun D.C.: Broskings Insticucion Press. 
Cunningham, James P. 1991. Vice President, Offshore Suurcing, the Gap (Far Last) Ltd., Hong Kong (Richard Appeibaum interview, November 28).

DeCuster, Jozet. 1996. "Hong Kong and China: The Joining of Two Gliarts in Textiles and Clothing." Textile Outlook Intemational 68 (November): 63-79.

DeGlopper, Donald R. 1995. Lakang: Commerte and Commonity in a Chinese Cit, Albany: SLiNY Press.

Dezality, Yvcs, Bryane Garth, and Pierre Bourdicu. 1998. Dualling in Viriue: Intchational

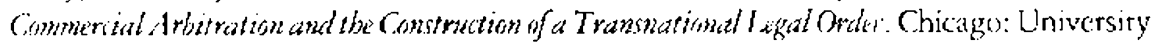
of Chicago Press.

Doner, Richard and Eric Hershberg. 1996. "Flexible Production and Political Decentralization: Elective Affinities in the Pursuit of Competitiveness?" Paper presented at the annual mecring of the American Political Science Association Meeting, San Francisco (Augusc).

East Asia Analytical Unit. 1995. Overseas Chmese Busintess Netuorks in Asia. Department of Foreign Affairs and Trade, The Australian Government, Canberra, Australia.

Fukuyama, Francis. 1995. Trust: The Social Virtuei and the Creation of Prosperity. New York: Iiree Press.

Gerefff, Gary, 1991. "Glohal Sourcing and Regional Divisions of Ialxor in the Pacific Rim." Paper prepared for Dirlik, Arif, What is in a Rini: Critical Perspectives on the Pacific Region Idea.

1992. "New Realities of Industrial Development in East Asia and Latin America: Cilobal, Regional, and National Trends." In States and Detelopment in the East Asian Paific Rim, eds. Richard P. Appelbaum and Jeffrey Henderson. Ncwbiry Park: Sage. 1994. "The Organization of Buyer-Driven Global Commodity Chains: How U.S. Retailers Shape Overseas Production Networks." In Commodity Cbains amd Global Capitalism, eds. Gary Gereffi and Miguel Korzeniewicz. Westport, Coml.: Grecnword Press.

Gereff, Gary and Tony Tam. 1998. "Industrial Legrading Through Organizational Chains: Dynamics of Rent, Learning-by-Doing, and Mobilicy in the Global Economy." Paper presented at the 93rd Annual Meeting of the American Sociological Association, Sar Francisco, Calif. (August 21-25).

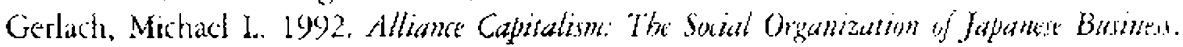
Bcrkelcy: University of California Press.

Granovetter, Mark. 1993. "Business Groups." In Haulbork of Eonomic Sainlugh, cdited by Neil Smelser and Richard Swedberg. New York: Russell Sage Foundacion.

Guthrie, Douglas. 1998. "Ihe Declining Significance of Qmuniz in China's Economic Transition." The Chima Querterly 154 (Junc) : 254-82.

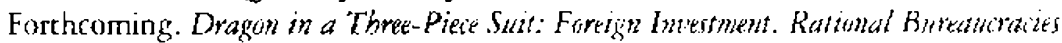
sant Market Reformi in Cbina. Princeton: Princeton University Press.

Hamashita, Takeshi. 1994. "The Tribute Tracie Systenu and Modern Aslit." In Japanese Induarialisation and the drian Econony', eds. A.J.H. Lathan and H. Kawakitsu. London and New York: Routledge.

Hamilton, Gary G. 1996. "Competition and Organization: A Re-cxamination of Chinese Business Practices." Jozmal of Asian Businers 12; 7-20.

. 1998. "Asian Business Networks in Transizions: What Alan Greenspan Doxes

Not Know About the Asian Business Crisis." Searte, Wash.: University of Washington, Department of Sociology (unpublished manuscript).

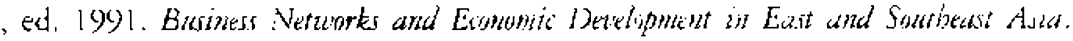
Hong Kong: Centre of Asıan Studies. 
1999. "Rcciprocity and Control: "Ihe. Organization of Chinese Bamily-Owned Conglomerites." Statte, Wash.: University of Washingten, Department of Sociology (unputzlished manuscript).

Hamileon, Gary G. and Kao, Cheng-shu. 1990. "The Institutional loundacions of Chinese Business: the Family Firm in Taiwan." Comparative Sacial Rescarch, Vol. 12: 1 i5-51. Hamilton, Gary $G$. and Robert C. leenstra. 1997. "Varicties of l licrarchics and Markets." In The Fonomic Oryanization of Fast Asian Capital, eds. Marco Orre, Nicole Woolscy Biggart, and Gary G. Hamilton. Thousand Oaks, Calif., London: Sage Publications. Harve), David. 1989. The Condition of Postmademity: An Enquing mo the Oriwins of Cultual Change. Cambridge, Mass: Blackwell.

Henderson, Jeffrey and Richard P. Appeilbaum. 1992. "Situating the State in the East

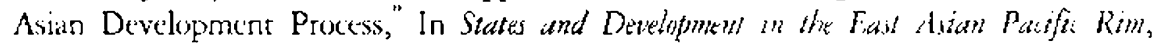
eds. Richard P. Appelbaum and Jeffrey Henderson. Newbury Park: Sage.

Hong Kong Industry Department. 1991. Hong Kong's Manufiziuring hndustrits, 1990. Hong Kong.

Hoovers. 1999. Hoover's On-Linc: Profiles for Wal-Mart, Sears, Kmart, and Daytun-Hudson (htrp:i/www hoovers.com/) (accessed $4 / 27 / 99$ ).

Hopkins, Terence K. and Immanuel Wallerstein. 1986. "Commodity Chains in the World-Economy Prior to 1800." Reriew 10 (1): 157.70.

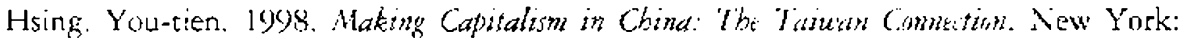
Oxford Liniversity P'ress.

l Iwang, Kwang-kwo. 1984. "Rujia Lunli yu Qiyc Zuzhi Xingtai." Zhongsum shi Guthli. Taipe: Gongshang Shibao.

Inoue, R., J. Kohama, and S. Lrata, eds. 1993. Indestrial Poliy' in bast Asia. 'Jokyo. Japan: Japan External Trade Organization.

Jones, Jackic. 1993. "Forces Behind Restructuring in U.S. Appared Rotailing and its Etfect in the U.S. Apparel Industry." L.S. International Trade Commission website ihttpiliww:usitc. gnv/332s/ITTREXMP.HTM).

Kawakatsu, Heita. 1986. "International Competitiveness in Cotton Goods in the Late Nineteenth Century: Britain versus India and East Asia." In The Eniergence "/ a World

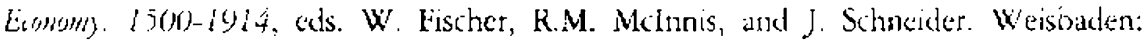
Frane Steiner Verlag.

Kingman, Matr. 199?. Senior Vice President of Sryl-land, PClf-Innova, Hong Kong (Brad Christerson intervicw, August 26).

Kojimia, K. 1977. Jatan and a New World Economii Order. Boulder, Colo.: Westfiew Press. Korzeniewicz, Miguel. 1994. "Commodity Chains and Marketing Stratcgics: Nike and

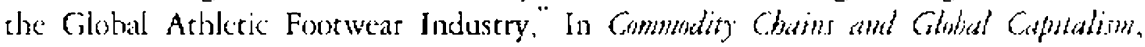
eds. Gary Gereffi and Miguel Korzeniewicz. Westport. Conn.: Greenuroot.

KSA. [90). Kurt Salmon Associates (KSA), "A Survival Course for the Nineties." KSA Peripetitit.

Landa. Janct, 1981. "A Theory of the Ethnicaly Homogencous Middleman Group: An

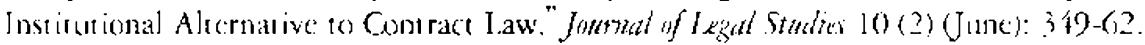

1998 . "Coascan Foundations of a Linified Theory of Western and Chinese Cont ractual Practices and Economic Organizations." Paper presented at the First Portuguesc Congress un Economic Sociology, liston, Porcugal (March 1-6).

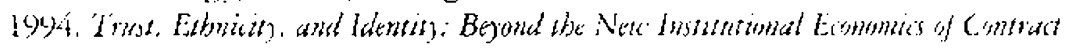




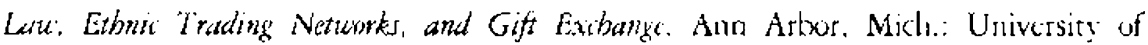
Michigan Press.

Lash, Scott and John Iirry. 1994. Economies of Sigms and Space. Thousand Oaks, Calif.: Sage.

Lau, Ho-Fuk, and Chi-Fai Chan. 1994. "The Developrnent Process of the Hong Kong Garment Industry: A Mature Industry in a Newly Industrialized Country." In Glowal Production: The Aptourd Industry in the Pacifi Rim, eds. Edna Bonacich, Lucic Cheng, Notma Chinchilla, Norma Hamilton, and Paul Ong. Philadelphia, Pa.: Temple University Press.

Leung, 1991. Leung Wing-yuc (Trini). 1991. 1 Iong Kong Trade Union Educational Center (TLEC) (Appxlbaum incerview, December 3).

Lui, Tai-lok. 1991. Iecturer, Deparment of Sociology. The Chinese Iniversiry of Hong Kong, Shatin, N.T., Hong Kong (Appelbaum interview, November 4).

1998. "Irust and Chinese Business Behavior," Hong Kong: Department of Sociology, Chinese University of I long Kong (unpublished paper).

Matkie, J.A.C. 1992. Overseas Chinese Entreprencurship. Ajan Paific Eomomic Litcrature 6: 41-64.

Ma, Lawrence. 1991. Ridewell Fashion and Sportswear Lrd., Hong Kong (Appelbaum interview. December 5).

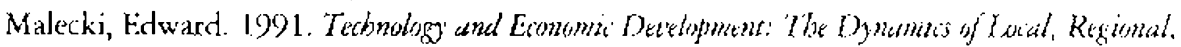
and National Change. New York: Iongman.

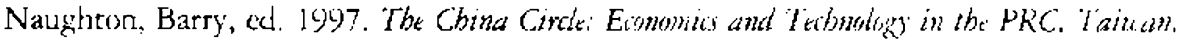
and Hong Kong. Washington D.C.: Bronkings insticution Press.

Ng. Ringo Ng. 1991. Vice President and General Manager, Mantratcan Industrics (Pas Fast) Y.ted. a division of Salant Corporation, Hong Kong (Richard Appollyaum intervicw, December?.

Nonini, Donald M. and Aihwa Ong. 14y7. "Chinese Transnationalism as an Alternative Modernity." In Ungrounded Enipires: The Cultural Politicio of Modern Chinese Transnationalism, eds. Aihwa Ong and Donald M. Nonini. New Yotk City: Routledget.

Numazaki. Ichiro. 1998. "The Export-Orienred Industrialization of Pacific Rim Nations and Their Presence in the Global Market." In The Four Ajian Tigers: Econtmic Derutupnumt and the Global Palitical Comnty, ed. Eun Mee Kim. New York: Acadenic Press.

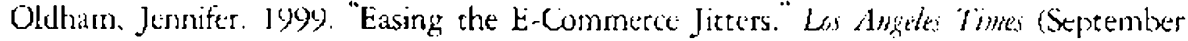
2): $\mathrm{C}-1$.

Oman, Charles. 1994. Globalization and Regionalisation: The Challenge for Deneloping Catmirien. Paris: OECD Development Centre Studies.

Ong. Aihwa. 1997. "Chinese Modernities: Narratives of Nation and of Capitalism." In Ungrounded Empires: The Cultural Politios of Modem Chinese Transmationalism, eds. Ailowa Ong and Donald M. Nonini. New York City: Roucledge.

Orr, Marro, Nicole Woolsey Biggart, and Gary G. Hamilton. 1992. "Organizational Isomorphism in East Asia: Broadening the New Institutionalism." In Thr Niu Instatutionalism in Onganizational Analysis. cdited by Walter W'. Powell and Paul J. DiMaggio. Chicago: Liniversity of Chicago Press.

OTEXA. 1999. LiS. Department of Commerce. Office of Textile and Appard Trade Development (OTEXA) Textile \& Apparcl Trade Balance Report: Imports, 4/20/99 (accessed 4/2790) (http:iotexa.ta.doc.gov/tbrimphth).

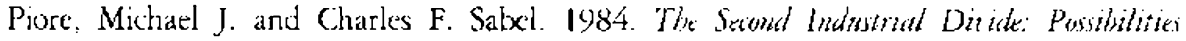


for Projperitj. Now York: Basic Borks.

Porrer, Michael E. 1990. The Competitite Adtantage of Nationi. New York: The Free Press. Redding, S. Gordon. 1990. The Spirit of Chinest Capitalism. New York: Walter deGruyter. Sassen, Saskia. 1988. The Mubility of Labor and Capital: Al Study in International Imetitment and Labor Flind. New York: Cambridge University P'ress.

Scout, Allen. 1988. "Flexible Production Systems and Regional Development." Internationat Joumal of lirhan and Reyignal Research Vol, 12: 171-86.

Smart. J. and A. Smart. 1991. "Personal Relations and Divergent Economics: A Case Study of Hong Kong Investment in South China." Imernational foural of Liban and Regismal Rejearih 15 (2): 216-33.

Steinberg, Michatel. 1996. [chair of Macy's West] cited in Kristin Young. "Federated Says it Will Boost California Country." Calforvia Apparel Nenes 4. November 5.

Storper, Michael and Richard Walker. 1989. The Capitalist lmperative: Temitnry, Technolngy and Industrial Grouth. New York: Basil Blackwell.

Sung Yun-wing. 1991. Senior Lecturer in Economics. The (hinese University of Hong Kung (Richard Apxibaum interview, November 4).

Tai-lok, Lui. 1998. "Trust and Chinese Business Behavior." Competition and Clange: The Joumal if Gilobal Buinsss and Politital Economy' 3 (3): 335-57.

The Ecmmind. 1992. "The Overseas Chinese: A Driving lource" July 18): 21-24.

'Tong, C.K and P.K. Yong. 1998. "Gnanxi Bases, Xinjong and Chinese Business Networks." Britid foumal of Srivilogy 49: 75-96.

Trocki, Carl A. 1997. "Boundaries and Transgressions: Chinese Enterprise in Eighteenthand Nineteench-Century Southeast Asia." In Ungrounded Empires: The Cultural Prilitio of Modern Chinese Transmationalism, eds. Aihwa Ong and Donald M. Nonini. New York City: Risutedgre.

Tsang. Paul C.M. 1991. General Manager, Unimix Limited, Hong Kong (Appelbaum intericw, November 28). July 17$)$.

1993. General Manager, Unimix Limited, 1 Iong Kong (Brak Christerson interview,

Watton, Steven R. 1993. Managing Director, Innova Ltd., Hong Kong (Apy)elbaum interview, May 2).

Whitley, Richard. 1992. Busimess Systems in East Ajia: Fimj, Markets, and Sucietits. Newbury Park, Calif:: Sage.

1996. "Business 5ystems and Global Commextiry Chains: Compecing or Complementary Forms of Economic Organization." Comptetitim and Chonge: The Jumbal of Clobal Business and Political Economy' I (4) (fall): $111-25$.

Wing Tai. 1991. Broxhure and Report.

Yamazawa, I. 1990. Economic Derelopment and Intematumal Thade: The Japunese Model. Honolulu, Hawaii: The Fast. West Center

Yan, Yunxiang. 1996. 'The Flow of Gifts: Recitracity and Silat Netuorks in a Cbineje Village. Palo Atro, Calif: Stanford University Press.

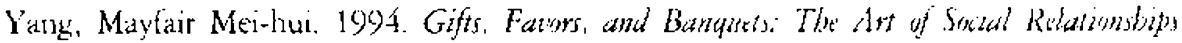
in China. Ithata, N.Y.: Cotnell University Press.

Yoshihara, Kunio. 1998. The Rise of Ersatz Capitaliom in Sinthicust diva. Oxtord: Oxford Liniversiry Press. 